\title{
Temporal variation of bacterial population and response to physical and chemical parameters along a petrochemical industry wastewater treatment plant
}

\author{
THEMIS C. ANTUNES, ANA E. BALLARINI and SUELI VAN DER SAND
}

Departamento de Microbiologia, Imunologia e Parasitologia, Instituto de Ciências Básicas da Saúde, Universidade Federal do Rio Grande do Sul, Rua Sarmento Leite, 500, 90050-170 Porto Alegre, RS, Brazil

Manuscript received on April 23, 2018; accepted for publication on September 24, 2018

\begin{abstract}
How to cite: ANTUNES TC, BALLARINI AE AND VAN DER SAND S. 2019. Temporal variation of bacterial population and response to physical and chemical parameters along a petrochemical industry wastewater treatment plant. An Acad Bras Cienc 91: e20180394. DOI 10.1590/0001-3765201920180394.
\end{abstract}

\begin{abstract}
The petrochemical industry has played a considerable role in generation and release of waste in the environment. Activated sludge and facultative lagoons are commonly used for domestic and industrial wastewater treatment due to their low-cost and minimal need for operational requirements. Microorganisms present in wastewater treatment plant (WWTP) are responsible for most nutrient removal. In this study, microbiological and physicochemical parameters were used to estimate changes in bacterial community in a petrochemical industrial WWTP. The activated sludge was the place with higher heterotrophic bacterial quantification. Denitrifying bacteria was reduced at least 5.3 times throughout all collections samples. We observe a decrease in the total Kjeldahl nitrogen, oxygen demand and phosphate throughout the WWTP. In this work, we also use Matrix-Assisted Laser Desorption Ionisation-Time-of-Flight Mass Spectrometry (MALDI-TOF MS) for bacteria isolates identification comparing with $16 \mathrm{~S}$ rDNA sequencing. The MALDITOF MS allowed the identification of $93 \%$ of the isolates and only $5 \%$ show different results from $16 \mathrm{~S}$ rDNA sequencing showing that the MALDI-TOF MS can be a tool for identifying environmental bacteria. The observation of microbial community dynamics in the WWTP is important in order to understand the functioning of the ecological structure formed in a specific environment.
\end{abstract}

Key words: bacteria, diversity, wastewater treatment, facultative lagoon, activated sludge.

\section{INTRODUCTION}

Petrochemical industry processing is responsible for the generation of large volumes of effluents characterized by contaminants such as iron, suspended solids, oils and fats, and hydrocarbons, among other inorganic ions (Wang et al. 2014). According to the National Water Agency from Brazil - ANA (Agencia Nacional das Águas 2013),

Correspondence to: Sueli Van Der Sand

E-mail: svands@ufrgs.br

ORCid: https://orcid.org/0000-0002-8591-6514 the industrial sector consumes approximately $18 \%$ of the total water intended for population uses. In view of their high toxicity, effective methods of effluent treatment should be investigated in order to protect human health and prevent damage to water resources (Piekutin and Skoczko 2016).

Biological treatment processes in the form of wastewater treatment plants (WWTPs) are the most widely used approach for treating municipal and industrial wastewater due to the high efficiency for organic matter removal and the low operational cost (Ye and Zhang 2013). Studies of seasonal variation 
are an alternative way to correlate environmental factors with bacterial community and function (Foster et al. 2003, Ju et al. 2014).

Fundamental knowledge regarding the microbial structure of effluent treatment is essential for understanding and improving the process and operation of those systems that use biological treatment. Although gene sequencing is the most frequently used method for identification, it is still an expensive and time-consuming method to be applied to wide populations and, therefore, alternative methods are necessary for the reliable identification of these bacteria, thereby shortening the time needed to achieve this process.

MALDI-TOF MS has gained popularity as a microbial biotyping tool due to its speed, lowcost, simplicity, and applicability for a wide range of microbes. It is becoming an increasingly essential technique for microbial characterization and identification in environmental microbiology and microbial diversity studies (Patil et al. 2015, Kopcakova et al. 2014, Busquets et al. 2014). MALDI-TOF MS has been used to identify environmental bacteria isolated from sludge (Ruelle et al. 2004) and industrial waste disposal (Kopcakova et al. 2014). Compared to other techniques, MALDITOF MS showed a high potential for the screening and discrimination of different environmental bacterial (Koubek et al. 2012).

Here, we aimed to evaluate the microbial community present in the wastewater treatment plant of Polo Petroquímico do Sul, Triunfo, Rio Grande do Sul, Brazil which consists of activated sludge and facultative lagoons. To evaluate diversity and changes in the microbial community we analyze microbiological, molecular and physicochemical parameters. Microbiological analyses aimed to estimate the amount of heterotrophic, denitrifying, sulfate-reducing, and nitrate-reducing bacteria in the WWTP and molecular analyses aimed to use MALDI-TOF MS techniques as a tool for identification of cultivable environmental microorganisms.

\section{MATERIALS AND METHODS}

\section{SAMPLING SITE}

The wastewater treatment plant is located at Triunfo city, Rio Grande do Sul, Brazil and uses activated sludge with mechanical aeration and eight facultative lagoons which operate in series (Fig. 1). The liquid effluent is mainly from industrial activity but also receives domestic wastewater. The wastewater effluent constitutes two streams: organic and inorganic. The organic requires a more complex treatment through physical-chemical and biological processes (biological treatment by prolonged aeration). The inorganic is cleaner and only needs a final polish. Organic liquid effluents are treated in three stages: in the primary stage, floating and coarse materials, separated oil and sand are eliminated and the liquid stream is equalized; in the secondary stage, the organic matter is eliminated through the biological process by activated sludge in the aeration tanks. Thereafter, this liquid stream passes through decantation. In the tertiary step, the remaining solids are removed by filtration. Finally, the treated effluent joins the inorganic and is conducted to the stabilization lagoons for final polishing. The effluent is finally disposed on the ground by sprinklers and perforated tubing. The excess of sludge, generated by the process, is disposed in the soil at a site called "Mud Farm".

For this study, the active sludge tank (AS) and four of the facultative lagoons (FL1, FL3, FL6, and FL8) were selected for microbial assays. For the physicochemical parameters, the sampling sites were the effluent input (API oil/ water separators) and the effluent output (Fig. 1). The main characteristics of the sampling sites are summarised in Table I.

Sampling was performed in May (collection 1 - C1), August (collection 2 - C2), and December 
TABLE I

Sampling sites points and their main characteristics.

\begin{tabular}{|c|c|c|c|c|c|}
\hline $\begin{array}{c}\text { Sampling sites/ } \\
\text { Coordinates }\end{array}$ & AS & FL1 & FL3 & FL6 & FL8 \\
\hline Size $\left(\mathrm{m}^{3}\right)$ & 50.000 & 150.000 & 406.000 & 269.000 & 103.000 \\
\hline Treatment & activated sludge & facultative lagoon & facultative lagoon & facultative lagoon & facultative lagoon \\
\hline $\begin{array}{l}\text { Hydraulic retention } \\
\text { time }\end{array}$ & 78 hours & 6 days & 21 days & 14 days & 5 days \\
\hline
\end{tabular}

AS: activated sludge tank. FL1, FL3, FL6, and FL8: facultative lagoons.

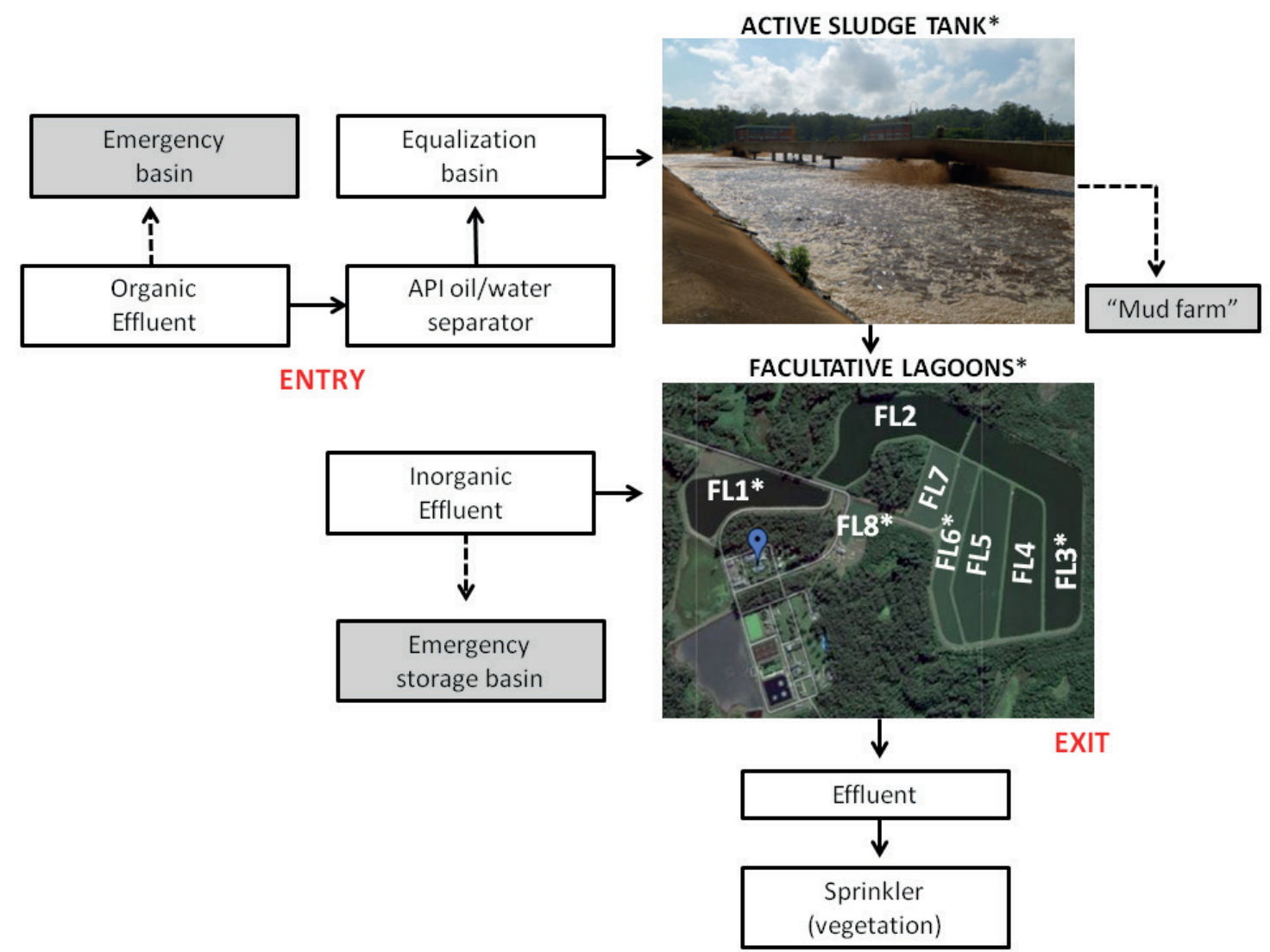

Figure 1 - Wastewater treatment plant pathway. $(\rightarrow)$ effluent pathway. The gray boxes represent emergency tanks for effluent and activated sludge overloads. *Collection points.

(collection 3 - C3) 2015, and March 2016 (collection 4 - C4). At each facultative lagoon (FL1, FL3, FL6, and FL8), $250 \mathrm{~mL}$ of water was collected from eight sampling points (1-8) of superficial water using a collection bucket with a three meters rope. For each lagoon, a pool of sampling was performed with a total volume of two liters of water per lagoon. At the activated sludge tank (AS), one liter of water was collected directly from the aeration tank using a collection bucket. Transportation of the samples to the laboratory was performed in cooler boxes.

\section{PHYSICOCHEMICAL CHARACTERIZATION OF WATER}

The physicochemical parameters were analysed according to the Standard Methods for the Examination of Water and Wastewater (SMEWW): total organic carbon (TOC) (SMEWW 22 $2^{\text {nd }} 5310$ ); 
chemical oxygen demand (COD) (SMEWW 22 $2^{\text {nd }}$ $5220 \mathrm{~B}$ ); total phosphate/orthophosphate(SMEWW $22^{\text {nd }} 4500$ ); ammoniacal nitrogen (SMEWW $22^{\text {nd }}$ 4500-NH3 B, C and F); total Kjeldahl nitrogen (NTK) (SMEWW 22 $2^{\text {nd }} 4500-\mathrm{NH} 3 \mathrm{~B}, \mathrm{C}$ and F), dissolved oxygen (DO) (SMEWW $22^{\text {nd }} 4500-\mathrm{O}-$ $\mathrm{G})$; dissolved solids (SD) (SMEWW $22^{\text {nd }} 2540 \mathrm{C}$ ); suspended solids (SS) (SMEWW $22^{\text {nd }} 2540 \mathrm{D}$ ); and total suspended solids (TSS) (SMEWW $22^{\text {nd }} 2540$ B). Temperature and $\mathrm{pH}$ were measured locally.

\section{MICROBIOLOGICAL ANALYSIS}

Samples were prepared according to the Standard Methods for the Examination of Water and Wastewater - APHA (2005).

\section{BACTERIAL QUANTIFICATION AND ISOLATION}

Mesophilic heterotrophic bacteria were determined on Plate Count Agar (PCA: tryptone $5.0 \mathrm{~g} / \mathrm{L}$, yeast extract $2.5 \mathrm{~g} / \mathrm{L}$, dextrose $1.0 \mathrm{~g} / \mathrm{L}$, agar $15 \mathrm{~g} / \mathrm{L}$ ) medium by the pour plate method. Samples were diluted in saline sodium chloride $0.9 \%$ solution. For the sludge samples, dilutions of $10^{-2}$ to $10^{-6}$ were performed, while the dilutions were $10^{-1}$ to $10^{-3}$ for the lagoon samples. After, $0.1 \mathrm{~mL}$ of each dilution was inoculated in plates containing de PCA medium. After, the plates were incubated at $25^{\circ} \mathrm{C}$ for $24-72$ hours. Bacterial colonies were chosen randomly for genomic DNA identification using MALDI-TOF MS and 16S rDNA sequence analysis.

\section{NITRATE-REDUCING BACTERIA}

The number of nitrate-reducing bacteria was estimated using the multiple-tube method describe by APHA (2005). To determine the most probable number (MPN) of nitrate-reducing bacteria, a series of 15 tubes distributed 5 out of 5 , containing each 10 $\mathrm{mL}$ of nitrate broth culture medium (peptic digest of animal tissue $5.0 \mathrm{~g} / \mathrm{L}$, meat extract $3.0 \mathrm{~g} / \mathrm{L}$ potassium nitrate $1.0 \mathrm{~g} / \mathrm{L}$, sodium chloride $30 \mathrm{~g} / \mathrm{L}$ ). In the first 5 tubes, $10 \mathrm{~mL}$ of the water sample to be examined was inoculated in each tube (dilution 1:1). In the remaining 10 tubes, 5 tubes were inoculated with 1 $\mathrm{mL}$ of the sample (dilution 1:10) and the last 5 tubes with $0.1 \mathrm{~mL}$ of the sample (dilution $1: 100$ ). The tubes were incubated at $30^{\circ} \mathrm{C}$ for $18-24$ hours. After the incubation period, five drops of each reagent $\mathrm{A}$ ( $8 \mathrm{~g}$ of sulphanilic acid in one liter of acetic acid) and B (5 g of alpha-naphthylamine in one-liter acetic acid) were added in each tube. The appearance of red or pink color indicates the reduction of nitrate. The estimation of bacteria nitrate reducers was obtained through the Most Probable Number tables (MPN) (APHA 2005).

\section{DENITRIFYING BACTERIA}

The determination of the MPN of denitrifying bacteria was performed through the multiple tubes technique using $8.0 \mathrm{~g} / \mathrm{L}$ of nutrient medium (peptone $5.0 \mathrm{~g} / \mathrm{L}$, sodium chloride $5.0 \mathrm{~g} / \mathrm{L}, \mathrm{HM}$ peptone B\# 1.5 $\mathrm{g} / \mathrm{L}$, yeast extract $1.5 \mathrm{~g} / \mathrm{L}$, agar $15 \mathrm{~g} / \mathrm{L}$ ) and $0.428 \mathrm{~g} / \mathrm{L}$ of sodium nitrate $\left(\mathrm{NaNO}_{3}\right.$. Himidea), accordingly Mendonça (2002). In the first 5 tubes $10 \mathrm{~mL}$ of the water sample to be examined was inoculated in each tube (dilution 1:1). In the remaining 10 tubes, 5 were inoculated with $1 \mathrm{~mL}$ of the sample (dilution 1:10) and 5 tubes inoculated with $0.1 \mathrm{~mL}$ of the sample (dilution 1:100). The tubes were incubated at $30^{\circ} \mathrm{C}$ for 15 days. After the tubes incubation period, drops of a solution of diphenylamine $2.0 \mathrm{~g}\left[\left(\mathrm{C}_{6} \mathrm{H} 5\right)_{2} \mathrm{NH}\right]$ and 1 liter of concentrated sulfuric acid $\left(\mathrm{H}_{2} \mathrm{SO}_{4}\right)$, was added to the tubes to check for the presence or absence of nitrate. The absence of staining after the reaction indicates the absence of nitrate and the possible presence of denitrifying bacteria (positive result), and blue staining indicates remaining nitrate, i.e. no denitrification (negative result). The estimation of denitrifying bacteria was obtained using the MPN tables (APHA 2005).

\section{SULPHATE-REDUCING BACTERIA}

The number of sulphate-reducing bacteria was determined by the multiple-tube method using SIM medium (tryptone $20 \mathrm{~g} / \mathrm{L}$, peptone $6.1 \mathrm{~g} / \mathrm{L}$, peptonized 
iron $0.2 \mathrm{~g} / \mathrm{L}$, sodium thiosulphate $0.2 \mathrm{~g} / \mathrm{L}$, agar 3.0 $\mathrm{g} / \mathrm{L}$ ) (Atlas 2005). In the first 5 tubes, $10 \mathrm{~mL}$ of the water 180 sample to be examined was inoculated in each tube (dilution 1:1). In the remaining 10181 tubes, 5 tubes were inoculated with $1 \mathrm{~mL}$ of the sample (dilution 1:10) and in the last 5182 tubes 0.1 $\mathrm{mL}$ of the sample into each tube (dilution 1:100). The tubes were incubated at $30^{\circ} \mathrm{C}$ for $24-48$ hours. The number of sulphate-reducing bacteria was estimated using an MPN table (APHA 2005).

DNA EXTRACTION

DNA was extracted following the instructions of the Wizard ${ }^{\circledR}$ Genomic DNA Purification Kit Protocol (Promega), with modifications. Cells were grown in brain heart infusion broth medium (brain heart infusion powder $17.5 \mathrm{~g} / \mathrm{L}$; proteose peptone $10 \mathrm{~g} / \mathrm{L}$; dextrose $2 \mathrm{~g} / \mathrm{L}$; sodium chloride $5 \mathrm{~g} / \mathrm{L}$; disodium phosphate $2.5 \mathrm{~g} / \mathrm{L}$ ) at $25^{\circ} \mathrm{C}$ for $24-48$ hours under agitation of $100 \mathrm{rpm}$. After that, cultures were centrifuged in an Eppendorf centrifuge (MiniSpin, Eppendorf AG, Hamburg, Germany) at 10.000 rpm and cells were resuspended in $50 \mathrm{mM}$ EDTA (Kasvi), pH 8.0, with lysozyme (Merk), at a final concentration of $1 \mathrm{mg} / \mathrm{mL}$ and incubated in a water bath at $37^{\circ} \mathrm{C}$ for $45 \mathrm{~min}$. Purity and concentration of the DNA were analyzed using the Nanodrop Spectrophotometer (K23-0002, KASVI).

\section{AMPLIFICATION, SEQUENCING, AND ANALYSIS OF 16S rDNA GENES}

The isolates were identified by sequencing of the $16 \mathrm{~S}$ rDNA region using the primers described in Table II (Edwards et al. 1989, Stackbrandt and Liesack
1993). PCR was performed in an Life Technology - Applied Biosystems ${ }^{\text {TM }}$ ProFlex ${ }^{\text {TM }}$ PCR System in $25 \mu \mathrm{L}$ reaction volume containing $1 \mathrm{x}$ PCR buffer (Invitrogen), $1.5 \mathrm{mM} \mathrm{MgCl}{ }_{2}$ (Invitrogen), 0.3 mM dNTPs (Invitrogen), $0.2 \mu \mathrm{M}$ of each primer (IDT), $1 \mathrm{U}$ de Taq polymerase (Invitrogen), $1 \mu \mathrm{L}$ of bacterial DNA $(50 \mathrm{ng} / \mu \mathrm{L})$. The PCR reaction was as follow: initial denaturation at $94^{\circ} \mathrm{C}$ for $5 \mathrm{~min}$, followed by 35 cycles of $94^{\circ} \mathrm{C}$ for $1 \mathrm{~min}, 59^{\circ} \mathrm{C}$ for $1 \mathrm{~min}, 72^{\circ} \mathrm{C}$ for $2 \mathrm{~min}$, final extension at $72^{\circ} \mathrm{C}$ for $10 \mathrm{~min}$, accordingly to Garbeva et al. (2003). The amplified products ( $\sim 1500 \mathrm{bp})$ were sequenced by Ludwig Biotec using an ABI-Prism 3500 Genetic Analyser (Applied Biosystems). The sequences obtained were analyzed and aligned with sequences available in the GenBank database using BLAST software (http://www.ncbi.nlm.nih.gov).

\section{MALDI-TOF MS ANALYSIS}

\section{Maldi-Tof MS (mdt) sample preparation}

For MALDI-TOF MS analysis, samples were grown in TSA medium (Himedia) for $24 \mathrm{~h}$. The extraction followed by the manufacturer MALDI Biotyper 4.0 (Bruker Daltonics, Germany). Bacteria were resuspended in $300 \mu \mathrm{L}$ of MiliQ water and $900 \mu \mathrm{L}$ of absolute ethanol was added. The mixture was centrifuged at $10.000 \mathrm{rpm}$ and the supernatant discarded. Residual ethanol was removed, and the pellet allowed drying at room temperature. Subsequently, $50 \mu \mathrm{L}$ of formic acid (70\%) (Merk) was added and mixed with the pellet by vortexing. Next, $50 \mu \mathrm{L}$ of acetonitrile (100\%) (Merk) was added and mixed. The solution was centrifuged

TABLE II

Primers used for the sequence of $16 \mathrm{~S}$ rDNA of isolates.

\begin{tabular}{cccc}
\hline Name & Sequence (5'-3') & Position ${ }^{\text {a }}$ & References \\
\hline BacPaeF $\left(\mathrm{pA}^{\mathrm{b}}\right)$ & AGAGTTTGATCCTGGCTCAG & $8-28$ & $\begin{array}{c}\text { Stackebrandt } \\
\text { and Liesack (1993) }\end{array}$ \\
Bac1542R $\left(1542 \mathrm{R}^{\mathrm{b}}\right)$ & AGAAAGGAGGTGATCCAGCC & $1525-1542$ & Edwards et al. (1989) \\
\hline
\end{tabular}

a position in E. coli, ${ }^{\mathrm{b}}$ reference citation. 
at $13.000 \mathrm{rpm}$ and $1 \mu \mathrm{L}$ of the supernatant was spotted on the MALDI target plate in two replicates. After drying, $1 \mu \mathrm{L}$ of the matrix solution (a-cyano- 4-hydroxycinnamic acid (HCCA, Bruker Daltonics, Germany) in 50\% acetonitrile and 2.5\% trifluoroacetic acid) was added to each spot and allowed to air dry. Samples were then processed in the MALDI-TOF MS spectrometer (MALDI Biotyper 4.0; Bruker Daltonics) with flex control software. Each spectrum was obtained by averaging 500 laser shots acquired in the automatic mode at the minimum laser power necessary for ionization of the samples. The spectra were analyzed in a $\mathrm{m} / \mathrm{z}$ ratio of 2-20 kDa. Data analysis was performed using the MALDI Biotyper Real-time Classification (MBT RTC) software (Bruker ${ }^{\circledR}$ ). MALDI-TOF MS spectrometer identifications were classified using score values proposed by the manufacturer. The score cut-offs recommended by the manufacturer ( $\geq 2.000$ for species-level, 1.700 to 1.999 for genus level and $<1.700$ no reliable identification were considered for identification.

\section{STATISTICAL ANALYSES}

Statistical analyses Student's T-test and ANOVA were performed by Past software (Hammer et al. 2001) were applied in the quantification of mesophilic heterotrophic bacteria between facultative lagoons at each period of sample collection (C1, C2, C3 and C4).

\section{RESULTS AND DISCUSSION}

PHYSICOCHEMICAL PARAMETERS AND MICROBIOLOGICAL ANALYSIS

Heterotrophic bacteria are microorganisms that degrade organic matter, mainly carbonaceous material, resulting in the reduction of BOD (biochemical demand of oxygen) and COD from the system. The COD is related to the amount of oxygen that the aerobic heterotrophic bacteria need to oxidize the organic matter present in the environment. In this study, the highest values for COD were observed in the collection C1 (399.5 $\mathrm{mg} / \mathrm{L})$ and C3 (637 mg/L) (Table III). These collections also showed the higher quantification for heterotrophic bacteria $1.64 \times 10^{6} \mathrm{CFU} / \mathrm{mL}$ and $6.40 \times 10^{5} \mathrm{CFU} / \mathrm{mL}$ respectively (Table IV). A decrease in the COD was observed together with an increase in oxygenation during the effluent treatment. The metabolic activity of heterotrophic bacteria is closely linked to COD since the degradation of organic matter results in the reduction of the COD from the system. Related to this, throughout the treatment system, DO increased in all performed collections together with a decrease of heterotrophic bacterial counts. Accordingly to Von Sperling (2002), the concentration of microorganisms' biomass is limited by the amount of substrate available, so it is expected a reduction of the microbial count when the organic matter, that is easily degradable, is no longer available.

Studies of biological processes involved in the bioconversion of pollutants present in the wastewater allow the observation of the relationship between the rate of oxygen consumption and the amount of substrate added (Svensson et al. 2015).

According to Van Haandel and Marais (1999), for heterotrophs, the proportion ratio for this is $1: 1$, that is, 1 unit of biodegradable soluble organic matter that will be oxidized will require 1 unit of oxygen for this oxidation. Experimental results indicate that the production of bacterial mass in oxidative metabolism is in the range of $0.35 \mathrm{~g}$ to $0.52 \mathrm{~g}$ of suspended volatile solids (VSS) per gram of metabolized COD, with $0.45 \mathrm{~g}$ of VSS per gram of metabolized COD being frequently used as mean value (Van Haandel and Marais 1999). That is, only one-third (33\%) of the organic matter tends to be directed to catabolic metabolism; the remainder $(67 \%)$ leading to anabolism. Such a ratio between the microbial mass synthesized and the metabolized COD mass is called the cellular 
TABLE III

Physicochemical parameters observed in samples collected from the Wastewater Treatment Plant.

\begin{tabular}{|c|c|c|c|c|c|c|c|c|}
\hline Site & C1a & C1b & $\mathrm{C} 2 \mathrm{a}$ & $\mathrm{C} 2 \mathrm{~b}$ & C3a & $\mathbf{C} 3 \mathbf{b}$ & $\mathrm{C} 4 \mathrm{a}$ & C4b \\
\hline TOC & 115.0 & 23.82 & 20 & 4.6 & 100 & 22 & 91 & 17 \\
\hline COD & 399.5 & 92.2 & 13.33 & 57.2 & 637 & 255.6 & 83.6 & 25 \\
\hline DO & 2.1 & 6.6 & 2.02 & 8.6 & 0.7 & 7.0 & 0.5 & 8.9 \\
\hline TSS & 1286 & 1273 & 788 & 730 & 1477 & 767 & 1625 & 1092 \\
\hline SS & 48 & 32 & 22 & 12 & 56 & 37 & 53 & 71 \\
\hline SD & 1241 & 1227 & 678 & 708 & 1428 & 733 & 1508 & 1016 \\
\hline FFO & 12.90 & 2.26 & 12.84 & 2.14 & 10.52 & 2.15 & 18.2 & 3.9 \\
\hline FFA & 12.74 & 1.91 & 9.23 & 1. 15 & 10.41 & 0.4 & 11.1 & 1.61 \\
\hline NTK & 67.67 & 21.85 & 13.08 & 4.36 & 25.54 & 4.09 & 27.53 & 4.11 \\
\hline AN & 8.74 & 20 & 4.32 & 1.16 & 11.49 & 1.53 & 8.44 & 0.42 \\
\hline
\end{tabular}

mg.L -1 $^{-}$(a) input; (b) output. C1 (May 2015); C2 (August 2015); C3 (December 2015); C4 (March 2016).

Total Organic Carbon (TOC); Chemical Oxygen Demand (COD); Dissolved Oxygen (DO); Total suspended solids (TSS); Solids suspended (SS); Solid Dissolved (SD); Total phosphorus (FFO); Phosphate (FFA); Total Kjeldahl Nitrogen (NTK); Ammoniacal Nitrogen (AN).

synthesis coefficient, growth coefficient or the coefficient of sludge yield.

In the treatment system studied here, there are two processes: activated sludge followed by stabilization lagoons. The second stage of the treatment might have contributed to increasing dissolved oxygen in the effluent due to the presence of cyanobacteria and algae in stabilization lagoons. In facultative lagoons, the biological process occurs with the coexistence of cyanobacteria and heterotrophic bacteria. Oxygen released by cyanobacteria through photosynthesis is consumed by heterotrophic bacteria that degrade organic matter, and these, in turn, release the carbonic gas that is used during cyanobacterial metabolism (Uehara and Vidal 1989, Morales et al. 2014). This positive balance of oxygen allows the occurrence of aerobic degradation processes of carbonaceous matter.

During the sampling of the stabilization lagoons, the mean $\mathrm{pH}$ was 8.5 , and the temperature ranged between $24^{\circ} \mathrm{C}$ and $29^{\circ} \mathrm{C}$, which favor the presence of cyanobacteria. According to Calijuri et al. (2006), environmental conditions for cyanobacteria are freshwater environments, a $\mathrm{pH}$ of 6.0 to 9.0 , and temperatures varying between 15 and $30^{\circ} \mathrm{C}$, with high concentrations of nutrients.

Among the physical-chemical parameters that must be determined in a waste treatment system are the organic and inorganic nutrients. Phosphorus and nitrogen are essential nutrients for the construction of the protein system. Data about their quantity are needed to evaluate the potential of a biological treatment, such as effluent treatment (Metcalf and Eddy 2003). On the other hand, the excess of nutrients in an aquatic environment, particularly nitrogen and phosphorus, can lead to the excessive growth of photosynthetic organisms causing eutrophication. Effluents from chemical industries and domestic sewage tend to have high concentrations of phosphorus (Von Sperling 2002) 
TABLE IV

Quantification of mesophilic heterotrophic bacteria in active sludge and facultative lagoons.

\begin{tabular}{cccccc}
\hline & AS & FL1 & FL3 & FL6 & FL8 \\
\hline C1 & $1.48 \mathrm{E}+06$ & $1.19 \mathrm{E}+05^{*}$ & $1.81 \mathrm{E}+04$ & $1.15 \mathrm{E}+04$ & $1.62 \mathrm{E}+04$ \\
$\mathrm{C} 2$ & $2.12 \mathrm{E}+05$ & $1.17 \mathrm{E}+05$ & $1.15 \mathrm{E}+05$ & $1.35 \mathrm{E}+05$ & $1.80 \mathrm{E}+04$ \\
$\mathrm{C} 3$ & $2.77 \mathrm{E}+05$ & $2.00 \mathrm{E}+05^{*}$ & $1.51 \mathrm{E}+05$ & $1.08 \mathrm{E}+04$ & $1.29 \mathrm{E}+04$ \\
$\mathrm{C} 4$ & $1.09 \mathrm{E}+05$ & $2.23 \mathrm{E}+04^{*}$ & $1.91 \mathrm{E}+04$ & $\underline{1.28 \mathrm{E}+03}$ & $\underline{1.36 \mathrm{E}+03}$ \\
\hline
\end{tabular}

Unit: $\mathrm{CFU} \mathrm{mL} \mathrm{m}^{-1}$. ${ }^{*}$ Tukey test $(\mathrm{p}=0.05)$ applied between facultative lagoons at each period of sample collection $(\mathrm{C} 1, \mathrm{C} 2, \mathrm{C} 3$ and C4) . Underline numbers are the lowest counts. (AS- active sludge; FL1- lagoon 1; FL3 - lagoon 3; FL6 - lagoon 6; FL8 - lagoon 8; C1 - collection 1; C2 - collection 2; C3 - collection 3; C4 - collection 4).

and, according to the Water Pollution Control Federation (1991), the effluents from the production fertilizers, protein product processing, petroleum refineries and chemical industries contain high concentrations of nitrogen.

Biological wastewater treatment plants based in activated sludge have been in charge of treating both domestic and industrial wastes and have constituted an essential instrument in environmental protection due to the removal of organic matter, suspended soils, nutrients (N, P) and pathogens (Bitton 2005).

Several populations of fast-growing ordinary heterotrophic organisms have been identified in active sludge. Genera like Pseudomonas, Flavobacterium and Acinetobacter (Amorim et al. 2014) are supposed to form extracellular polymeric substances matrices that embed microcolonies of slower growing heterotrophic populations of slow-growing polyphosphate- (PAOs), glycogenaccumulating organisms (GAOs), and autotrophic populations of nitrifiers and anammox bacteria (Weissbrodt et al. 2013, Winkler et al. 2012).

Bacillus sp. can metabolize a variety of compounds including carbohydrates, proteins, peptides and amino acids for growth and energy. Some of the major products produced from carbon sources such as sucrose or glucose during anaerobic respiration include L-lactate, acetate, formate, succinate, ethanol, and carbon dioxide (Mols et al. 2007).
Alcaligenes sp. are well-known aerobic denitrifiers genera involved denitrification function in active sludge (Tian et al. 2015) and also are related to biodegradation of volatile organic sulfur compounds (Yiming et al. 2016)

Some microorganisms are commonly found in the gastrointestinal tract of humans such as Enterobacteriaceae (Lawrence 2014) and Enterococcus sp. (Nachtigall et al. 2013). The input of domestic sewage together with industrial effluent may have caused the presence of these microorganisms.

In this study, the correlation between phosphate and DO was -0.94 , showing a high relation between these two parameters for this type of treatment. We observed a reduction in the phosphorus and total nitrogen values and an increase in DO during the treatment of the effluent. Algae metabolism in the facultative lagoon may have contributed to ammoniacal nitrogen consumption since these organisms use ammonia as a nutritional source for their cellular metabolism (Valero et al. 2010). Thus, nitrifying bacteria might also have helped in the nitrogen reduction, since in the nitrification phase, under aerobic conditions, the ammonium is oxidized in two phases: in the first, ammoniaoxidizing bacteria (AOB) oxidate ammonium to nitrite, and subsequently, nitrite-oxidizing bacteria (NOB) oxidate nitrite to nitrate (Chang et al. 2011, Muñoz et al. 2009). 
Nitrifying bacteria are sensitive to different environmental and operational factors that can directly influence their metabolism in ways that interfere with their growth. The main parameters of this process are temperature, $\mathrm{pH}$, dissolved oxygen content, the presence of ammoniacal nitrogen, and toxic or inhibitory substances (Grunditz and Dalhammar 2001). In this study, a reduction of nitrifying bacteria from $1600 \mathrm{MPN} / \mathrm{mL}$ to 220 $\mathrm{MPN} / \mathrm{mL}$ was observed throughout the treatment plant (Table V). The highest total quantification of nitrifiers occurred at collection $\mathrm{C} 1$. The coexistence of nitrifying and heterotrophic bacteria in the same ecosystem leads, in most cases, to compete for the available oxygen. When heterotrophic predominance occurs, nitrogen removal rates are directly affected. This heterotrophic and nitrifying ratio may have interfered with the total nitrogen removal index since, among the samples collected, $\mathrm{C} 1$ presented the second-lowest rate of removal. Collection $\mathrm{C} 3$ and $\mathrm{C} 4$ correspond to the samples with the highest rates of removal of ammoniacal nitrogen (86.86\% and $95.02 \%)$ and total nitrogen (83.99\% and $85.07 \%)$, and also presented the lowest quantification of heterotrophic bacteria.
Another factor that may have influenced the rate of nitrogen removal is related to $\mathrm{pH}$. In this study, we recorded $\mathrm{pH}$ values of $\cong 6.6$ (activated sludge) and $\cong 8.0$ (mean of stabilization lagoons) for samples collection $\mathrm{C} 1$ and $\mathrm{C} 2$ respectively and $\cong 7.1$ (activated sludge) and $\cong 9.0$ (mean of the stabilization lagoons) for $\mathrm{C} 3$ and $\mathrm{C} 4$ respectively. The nitrification rate has an optimum $\mathrm{pH}$ range of 7.2 to 8.0; considerably decreasing at $\mathrm{pH}$ below 6.0. According to Metcalf and Eddy (2003), for $\mathrm{pH}$ values of the effluent close to neutrality (6.0 to 8.0), almost all ammoniacal nitrogen (more than 90\%) is in the form of ammonium ion $\left(\mathrm{NH}_{4}^{+}\right)$, favoring the nitrification process. In this sense, Jeschke et al. (2013) stated that the accumulation of ammonia observed in natural environments or treatment systems is due to the inhibition of the process caused by acidic $\mathrm{pH}$ values in the reaction medium.

Another important factor to be considered is the concentration of dissolved oxygen in the effluent. In the, $\mathrm{C} 3$ and $\mathrm{C} 4$ samples, the values observed were 0.7 and $0.5 \mathrm{mg} / \mathrm{L}$ respectively, close to the critical concentration rate of $0.2 \mathrm{mg} / \mathrm{L}$ recommended by Von Sperling (2002) for the nitrification process to occur. On the other hand, the concentration

TABLE V

Quantification of sulfate-reducing, nitrifying, and denitrifying bacteria collected from active sludge and facultative lagoons.

\begin{tabular}{|c|c|c|c|c|c|}
\hline Test & Site & $\mathrm{C1}$ & $\mathrm{C2}$ & $\mathrm{C3}$ & $\mathrm{C} 4$ \\
\hline Sulfate-reducing & AS to FL8 & $>1600$ & $>1600$ & $>1600$ & $>1600$ \\
\hline \multirow{5}{*}{$\begin{array}{c}\text { Nitrifying } \\
\text { bacteria }\end{array}$} & AS & $>1600$ & $>1600$ & $>1600$ & $>1600$ \\
\hline & FL1 & $>1600$ & 280 & 1600 & 900 \\
\hline & FL3 & $>1600$ & 220 & 900 & 280 \\
\hline & FL6 & $>1600$ & 2 & 280 & 220 \\
\hline & FL8 & $>1600$ & 2 & 220 & 2 \\
\hline \multirow{5}{*}{$\begin{array}{c}\text { Denitrifying } \\
\text { bacteria }\end{array}$} & AS & 1600 & 1600 & 1600 & 1600 \\
\hline & FL1 & 170 & 350 & 350 & 1600 \\
\hline & FL3 & 170 & 280 & 350 & 300 \\
\hline & FL6 & 170 & 220 & 210 & 300 \\
\hline & FL8 & 170 & 140 & 110 & 300 \\
\hline
\end{tabular}

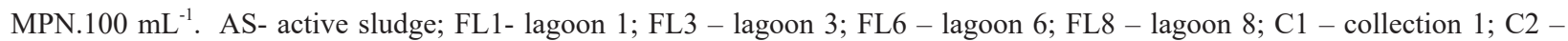
collection 2; C3 - collection 3; C4 - collection 4 . 
observed at collection C1 was $2.1 \mathrm{mg} / \mathrm{L}$. Higher values should be maintained in the aeration tank so that, in all regions, the concentration of dissolved oxygen is higher than the critical concentration. According to Hidaka et al. (2002), oxygen is one of the most relevant parameters in nitrification, since concentrations lower than $2 \mathrm{mg} \mathrm{O}_{2} / \mathrm{L}$ may partially or totally limit the activity of nitrifying bacteria.

In stabilization lagoons, nitrogen removal occurs mainly through algae absorption, settling, and soil adsorption (Pirsaheb et al. 2014). Pirsaheb et al. (2014) and Soares et al. (1996) have shown that stabilization lagoons systems have low nitrogen removal efficiency and require complementary processes to improve the final effluent.

Traditionally, denitrification occurs only under anaerobic or anoxic conditions, thus restricting the occurrence of denitrification for nitrification in different zones (Zhu et al. 2008). However, new aerobic denitrifying bacteria have been reported (Guo et al. 2013) compared to conventional nitrogen removal systems. These bacteria can oxidize ammonia to nitrite and simultaneously reduce nitrite and nitrate to gaseous nitrogen through aerobic denitrification (Guo et al. 2013). In the present work, the presence of denitrifying bacteria was observed in the activated sludge and along the stabilization lagoons. In the activated sludge system, the presence of dead zones in which aeration is not sufficient and the formation of micro niches with a low concentration of oxygen may have favored the metabolism of the denitrifying bacteria. We observe no difference along the MPN counting for facultative lagoon in $\mathrm{C} 1$ along all the collections. This result may have been caused by insufficient dilution of the sample.

During the collection, DO input values were between 0.5 and $2.1 \mathrm{mg} / \mathrm{L}$ and the low oxygen concentration may have favored the conversion of nitrate to gaseous nitrogen, nitrous oxide or both. Denitrification processes have also been observed in biofilms (Kadlec and Knigth 1996) and in systems where there is a low concentration of DO. Tallec et al. (2008) observed the occurrence of denitrification under low oxygen concentration in a municipal sewage treatment system. In this study, there was a decrease in the denitrifiers counts during the serial treatment of the stabilization lagoons. This result can be related to the increase of oxygen concentration resulting from the photosynthetic process of the algae present in this environment, thus disfavoring the denitrification process.

As nitrification, denitrification has as factors influencing the process: the dissolved oxygen concentration, temperature, $\mathrm{pH}$, and the quality and quantity of carbon sources (Tonetti et al. 2013). According to Metcalf and Eddy (2003) and Surampalli et al. (1997), the ideal temperature range for the denitrification process is between $10^{\circ} \mathrm{C}$ and $30^{\circ} \mathrm{C}$, and denitrification increases with temperature elevation until the optimum value of $40^{\circ} \mathrm{C}$ (Van Haandel and Marais 1999). In relation to $\mathrm{pH}$ the optimum range shows a variation according to different authors (Henze et al. 1994, Metcalf and Eddy 2003, Glass and Silverstein 1998) and when the $\mathrm{pH}$ is less than 6.0 there is a great reduction of denitrifying activity leading to the accumulation of nitrite or nitrate in the system.

An essential goal of wastewater treatment of domestic and industrial waste is the targeted removal of nitrogen, which is present at high levels for bacterial growth requirements with the available carbon. Alternating nitrification and denitrification is the overall process responsible for nitrogen removal from biological nutrient removal in activated sludge wastewater treatment plants (McIlroy et. al. 2016).

Studies in WWTPs suggested a higher diversity of active denitrifiers, including uncharacterized members of the Alphaproteobacteria, Gammaproteobacteria, and Actinobacteria (Osaka et al. 2006, Hagman et al. 2008, Morgan-Sagastume et al. 2008). 
Certain groups of heterotrophic nitrificationaerobic denitrification microorganisms, such as Alcaligenes faecalis, Pseudomonas stutzeri and Bacillus sp. have been isolated from soils and wastewater treatment systems (Joo et al. 2005, Kim et al. 2008, Yang et al. 2011). These heterotrophic nitrifying-aerobic denitrifying microorganisms capable of nitrification and denitrification simultaneously under aerobic presented advantages as applied for nitrogen removal: (i) methodology simplicity, nitrification, and denitrification can take place simultaneously; (ii) less acclimation problems; (iii) lesser buffer quantity needed because alkalinity generated during denitrification can partly compensate for the alkalinity consumption in nitrification (Zhao et al. 2010, Yao et al. 2013).

In the present work, the presence of sulfate reducing bacteria (SRB) was observed in all points of collection. Van den Brand et al. (2015) detected the presence of SRB in nine activated sludge wastewater treatment plants by analyzing the population diversity of SBR and the effect on SBR metabolism at prolonged oxygen exposure. The authors also observed a seasonal (winter and summer) impact on the SRB population and the most common and dominant species were Desulfobacter postgatei, Desulfovibrio desulfuricans, and Desulfovibrio intestinalis. The occurrence of SBR in WWT has also been reported by Manz et al. (1998) using in situ probes in different stages of the activated sludge process, where the presence of Desulfobacteriaceae and Desulfovibrionaceae was observed in anaerobic, anoxic, and aerobic zones. Van den Brand et al. (2015) advocates that SRB grow in granules in order to protect them from exposure to oxygen, so they are naturally present in the aerobic WWTP due to the formation of these elements.

PERFORMANCE OF MALDI-TOF MS COMPARED TO 16S rDNA SEQUENCE

The MALDI-TOF MS technique (MDT) allowed the identification of $68(93 \%)$ of the 73 isolates at the genus or species level. Considering the total of the isolates identified $(n=68), 19 \%(n=14)$ were identified at the species level (score $\geq 2.000$ ) and $74 \%(n=54)$ at the genus level (score of 1.700 $1.999)$. Five (7\%) of the isolates scored below 1.700 no reliable identification (NRI) and could not be identified by the MDT due to the absence of peaks correlated to the species or genus in the Biotyper 2.0 database.

Identification using $16 \mathrm{~S}$ rDNA allowed the identification of $41 \%(n=30)$ isolates at genus level and $59 \%(n=43)$ at the species level (similarity $\geq$ 97). No divergence was found between the results obtained by the two techniques, MALDI-TOF MS and $16 \mathrm{~S}$ rDNA, for the isolates that were possible to perform identification at the genus or species level.

In some cases, the MDT method was able to identify a high taxonomic level than $16 \mathrm{~S}$ rDNA, isolate 26 (Microbacterium oxidans), isolate 38 (Alcaligenes faecalis) and isolates 7, 29, 72 (Acinetobacter pitii.) the MDT method was able to identify samples at the species level while $16 \mathrm{~S}$ rDNA was only at the genus level (Table VI).

The MALDI-TOF MS is becoming increasingly essential for the characterization and identification of microorganisms in environmental microbiology and microbial diversity studies (Kopcakova et al. 2014, Busquets et al. 2014).

Kopcakova et al. (2014) identified less than $20 \%$ of the bacterial isolates from industrial waste at the species level, and $43 \%$ of the isolates were not identified by the MDT technique. Urwyler and Glaubitz (2016) evaluated the performance MALDI-TOF MS (Bruker and Vitek) phenotyping on industrial isolates in comparison with biochemical-based phenotyping and genotyping. At the genus level, both MALDI-TOF MS based systems showed the lowest number of false (4\%) identifications and approximately $60 \%$ correct identifications. 
TABLE VI

Isolates identification using MALDI-TOF MS and 16SrDNA.

\begin{tabular}{|c|c|c|c|c|c|c|}
\hline \multicolumn{4}{|c|}{ MALDI-TOF MS } & \multicolumn{3}{|c|}{ 16S rDNA } \\
\hline Collection & Isolate & Identification & Score & Identification & Similarity & GenBak \\
\hline $\mathrm{C} 1$ & 7 & Acinetobacter pittii & 2.3 & Acinetobacter sp. & $98 \%$ & KX639781.1 \\
\hline $\mathrm{C} 1$ & 14 & Acinetobacter pittii & 2.2 & Acinetobacter calcoaceticus & $96 \%$ & KR262850.1 \\
\hline $\mathrm{C} 1$ & 9 & Alcaligenes faecalis & 2.0 & Alcaligenes sp. & $98 \%$ & KY476152.1 \\
\hline $\mathrm{C} 1$ & 19 & Arthrobacter creatinolyticus & 1.8 & Arthrobacter creatinolyticus & $96 \%$ & KC456596.1 \\
\hline $\mathrm{C} 1$ & 12 & Bacillus cereus & 2.3 & Bacillus cereus & $98 \%$ & JQ660597.1 \\
\hline $\mathrm{C} 1$ & 18 & Bacillus cereus & 2.0 & Bacillus sp. & $98 \%$ & KY476301.1 \\
\hline $\mathrm{C} 1$ & $1 \mathrm{~A}$ & Bacillus pumilus & 1.8 & Bacillus pumilus & $99 \%$ & HQ202554.1 \\
\hline $\mathrm{C} 1$ & 2 & Bacillus pumilus & 2.0 & Bacillu spumilus & $99 \%$ & KR152300.1 \\
\hline $\mathrm{C} 1$ & 17 & Bacillus pumilus & 2.0 & Bacillus pumilus & $99 \%$ & JX083967.1 \\
\hline $\mathrm{C} 1$ & 15 & Bacillus subtilis & 2.1 & Bacillus sp. & $98 \%$ & KF746888 \\
\hline $\mathrm{C} 1$ & 8 & Lelliottia amnigena & 1.7 & Lelliottia amnigena & $95 \%$ & MF581413.1 \\
\hline $\mathrm{C} 1$ & 11 & $\begin{array}{c}\text { Microbacterium } \\
\text { hydrocarbonoxydans }\end{array}$ & 1.9 & Microbacterium phyllosphaerae & $98 \%$ & FJ613556.1 \\
\hline $\mathrm{C} 1$ & 5 & Microbacterium oxydans & 2.2 & Microbacterium oxydans & $97 \%$ & KF358264.1 \\
\hline $\mathrm{C} 1$ & 10 & Microbacterium oxidans & 2.0 & Microbacterium sp. & $96 \%$ & JQ012995.1 \\
\hline $\mathrm{C} 1$ & 1 & Micrococcus luteus & 2.3 & Micrococcus luteus & $97 \%$ & KY007582.1 \\
\hline $\mathrm{C} 1$ & 6 & Providencia rettgeri & 2.5 & Providencia rettgeri & $98 \%$ & СР017671 \\
\hline $\mathrm{C} 1$ & 3 & NRI & 1.3 & Myroides phaeus & $97 \%$ & NR117475.1 \\
\hline $\mathrm{C} 1$ & 4 & NRI & 1.3 & Myroides phaeus & $97 \%$ & NR117475.1 \\
\hline $\mathrm{C} 1$ & 13 & NRI & 1.3 & Gordonia amicalis & $97 \%$ & KU904410.1 \\
\hline $\mathrm{C} 1$ & 16 & NRI & 1.3 & Myroides phaeus & $97 \%$ & NR117475 \\
\hline $\mathrm{C} 2$ & 29 & Acinetobacter pittii & 2.3 & Acinetobacter sp. & $98 \%$ & KX639781.1 \\
\hline $\mathrm{C} 2$ & 38 & Alcaligenes faecalis & 2.3 & Alcaligenes sp. & $98 \%$ & KF735809.1 \\
\hline $\mathrm{C} 2$ & 28 & Aneurinibacillus aneurinilyticus & 2.8 & Aneurinibacillus aneurinilyticus & $98 \%$ & KY744681.1 \\
\hline $\mathrm{C} 2$ & 41 & Aneurinibacillus aneurinilyticus & 1.9 & Aneurinibacillus aneurinilyticus & $98 \%$ & JX290554.1 \\
\hline $\mathrm{C} 2$ & 31 & Bacillus cereus & 2.2 & Bacillus cereus & $98 \%$ & JQ660597.1 \\
\hline $\mathrm{C} 2$ & 25 & Bacillus pumilus & 2.0 & Bacillus pumilus & $99 \%$ & JX083967.1 \\
\hline $\mathrm{C} 2$ & 35 & Bacillus pumilus & 1.9 & Bacillu sp. & $98 \%$ & KJ184909.1 \\
\hline $\mathrm{C} 2$ & 43 & Bacillus pumilus & 1.7 & Bacillus pumilus & $98 \%$ & KX832718 \\
\hline $\mathrm{C} 2$ & 33 & Bacillus safensis & 1.7 & Bacillus sp. & $99 \%$ & KY625521 \\
\hline $\mathrm{C} 2$ & 20 & Enterobacter asburiae & 2.0 & Enterobacter asburiae & $97 \%$ & GU003846.1 \\
\hline $\mathrm{C} 2$ & 22 & Microbacterium oxidans & 2.2 & Microbacterium sp. & $96 \%$ & JQ012995.1 \\
\hline $\mathrm{C} 2$ & 26 & Microbacterium oxidans & 2.3 & Microbacterium sp. & $96 \%$ & JQ012995.1 \\
\hline $\mathrm{C} 2$ & 24 & Sthapylococcus warneri & 2.1 & Staphylococcus pasteuri & $97 \%$ & KX387355.1 \\
\hline $\mathrm{C} 2$ & 27 & Pseudomonas mendocina & 1.9 & Pseudomonas sp. & $98 \%$ & KC294058.1 \\
\hline $\mathrm{C} 2$ & 32 & Pseudomonas mendocina & 2.0 & Pseudomonas sp. & $98 \%$ & KC294058.1 \\
\hline $\mathrm{C} 2$ & 39 & Pseudomonas mendocina & 2.1 & Pseudomonas sp. & $98 \%$ & KC294058.1 \\
\hline $\mathrm{C} 2$ & 23 & Pseudomonas oleovorans & 2.0 & Pseudomonas sp. & $98 \%$ & KC294058.1 \\
\hline
\end{tabular}


TABLE VI (continuation)

\begin{tabular}{|c|c|c|c|c|c|c|}
\hline \multicolumn{4}{|c|}{ MALDI-TOF MS } & \multicolumn{3}{|c|}{ 16S rDNA } \\
\hline Collection & Isolate & Identification & Score & Identification & Similarity & GenBak \\
\hline $\mathrm{C} 2$ & 37 & NRI & 1.3 & Acinetobacter calcoaceticus & $98 \%$ & KR262850.1 \\
\hline $\mathrm{C} 3$ & 45 & Bacillus sp. & 1.7 & Bacillus sp. & $98 \%$ & KU986673 \\
\hline $\mathrm{C} 3$ & 52 & Bacillus altitudinis & 1.8 & Bacillus sp. & $99 \%$ & KU644503.1 \\
\hline $\mathrm{C} 3$ & 56 & Brevibacillus agri & 2.0 & Brevibacillus agri & $98 \%$ & KY818990 \\
\hline $\mathrm{C} 3$ & 49 & Bacillus cereus & 2.2 & Bacillus cereus & $98 \%$ & KU573976.1 \\
\hline $\mathrm{C} 3$ & 51 & Bacillus marisflavi & 1.8 & Bacillus sp. & $99 \%$ & KF746888 \\
\hline $\mathrm{C} 3$ & 48 & Bacillus pumilus & 1.7 & Bacillus sp. & $98 \%$ & KJ184909.1 \\
\hline $\mathrm{C} 3$ & 58 & Bacillus pumilus & 1.8 & Bacillus pumilus & $99 \%$ & JX083967.1 \\
\hline $\mathrm{C} 3$ & 59 & Bacillus pumilus & 1.9 & Bacillus pumilus & $98 \%$ & KX832718 \\
\hline $\mathrm{C} 3$ & 61 & Bacillus pumilus & 1.8 & Bacillus sp. & $97 \%$ & GU377066 \\
\hline $\mathrm{C} 3$ & 65 & Bacillus pumilus & 1.8 & Bacillus pumilus & $99 \%$ & JX083967.1 \\
\hline $\mathrm{C} 3$ & 44 & Brevibacillus borstelensis & 2.3 & Brevibacillus sp. & $98 \%$ & KP795806.1 \\
\hline $\mathrm{C} 3$ & 60 & Enterobacter asburiae & 2.3 & Enterobacter asburiae & $97 \%$ & GU003846.1 \\
\hline $\mathrm{C} 3$ & 63 & Enterococcus faecium & 2.3 & Enterococcus faecium & $99 \%$ & KM495940 \\
\hline $\mathrm{C} 3$ & 62 & Lysinibacillus boronitolerans & 2.2 & Lysinibacillus sp. & $99 \%$ & KY576798 \\
\hline $\mathrm{C} 3$ & 64 & Lysinibacillus boronitolerans & 2.0 & Lysinibacillus sphaericus & $98 \%$ & KX908032.1 \\
\hline $\mathrm{C} 3$ & 50 & Lysinibacillus fusiformis & 1.8 & Lysinibacillus sphaericus & $98 \%$ & CP015224.1 \\
\hline $\mathrm{C} 3$ & 57 & Lysinibacillus fusiformis & 2.2 & Lysinibacillus sphaericus & $98 \%$ & СР015224 \\
\hline $\mathrm{C} 3$ & 46 & Pantoea ananatis & 2.1 & Pantoea ananatis & $98 \%$ & KM884897.1 \\
\hline $\mathrm{C} 3$ & 47 & Pseudomonas putida & 1.7 & Pseudomonas putida & $99 \%$ & KT380508 \\
\hline $\mathrm{C} 4$ & 75 & Alcaligenes faecalis & 2.1 & Alcaligenes faecalis & $96 \%$ & KT013264.1 \\
\hline $\mathrm{C} 4$ & 72 & Acinetobacter pittii & 2.3 & Acinetobacter sp. & $98 \%$ & CR543861.1 \\
\hline $\mathrm{C} 4$ & 70 & Bacillus cereus & 1.9 & Bacillus cereus & $99 \%$ & JQ660597.1 \\
\hline $\mathrm{C} 4$ & 66 & Bacillus cereus & 2.1 & Bacillus sp. & $99 \%$ & KY379943.1 \\
\hline $\mathrm{C} 4$ & 67 & Bacillus pumilus & 1.9 & Bacillus pumilus & $99 \%$ & JX083967.1 \\
\hline $\mathrm{C} 4$ & 68 & Bacillus pumilus & 1.8 & Bacillus sp. & $98 \%$ & KJ184909.1 \\
\hline $\mathrm{C} 4$ & 69 & Bacillus pumilus & 1.7 & Bacillus pumilus & $99 \%$ & JX083967.1 \\
\hline $\mathrm{C} 4$ & 71 & Bacillus pumilus & 2.0 & Bacillus pumilus & $99 \%$ & JX083967.1 \\
\hline $\mathrm{C} 4$ & 81 & Bacillus pumilus & 1.8 & Bacillus pumilus & $99 \%$ & HQ202554.1 \\
\hline $\mathrm{C} 4$ & 77 & Bacillus safensis & 1.7 & Bacillus safensis & $99 \%$ & KT758564.1 \\
\hline $\mathrm{C} 4$ & 79 & Bacillus safensis & 1.8 & Bacillus safensis & $99 \%$ & KT758564.1 \\
\hline $\mathrm{C} 4$ & 73 & Kosakonia cowanii & 2.0 & Kosakonia cowanii & $95 \%$ & СР019447.1 \\
\hline $\mathrm{C} 4$ & 74 & Lysinibacillus boronitolerans & 1.9 & Lysinibacilluss phaericus & $98 \%$ & KX908032.1 \\
\hline $\mathrm{C} 4$ & 78 & Lysinibacillus boronitolerans & 2.3 & Lysinibacillus sp. & $98 \%$ & KY576798 \\
\hline $\mathrm{C} 4$ & 76 & Micrococcus luteus & 2.0 & Micrococcus luteus & $98 \%$ & KY007582.1 \\
\hline $\mathrm{C} 4$ & 80 & Providencia rettgeri & 2.5 & Providencia rettgeri & $99 \%$ & MF100122.1 \\
\hline $\mathrm{C} 4$ & 82 & Providencia rettgeri & 1.8 & Providencia rettgeri & $98 \%$ & KU052647.1 \\
\hline
\end{tabular}


On the other hand, the limited number of spectra in the database of MALDI-TOF MS includes few varieties of non-clinical origin and presents a low percentage of identification (43-65\%) for microorganisms isolated from soil, water, and other environments (Rahi et al. 2016). In addition, there is a need to increase the existing MALDI-TOF MS databases with more diverse microorganism spectra. Isolates identified as Myroides phaeus (3, 4 and 16) and Gordonia amicalis (13) by $16 \mathrm{~S}$ rDNA sequencing have no spectra in the MALDI-TOF MS database. The development of an open, online and universal access to databases would allow in-house data exchange between research groups. Therefore, it is expected that the availability of updated and robust databases, together with optimized methods and protocols, will allow the extensive use of this technique in the field of environmental microbiology, microbial ecology, and taxonomy.

Other factors that affect the identification by MDT are the inability of the spectra to differentiate between very similar species (Bizzini et al. 2011) and the fact that some taxonomic groups are still an identification challenge for both MD and 16S rDNA, such as the Bacillus cereus complex, Burkholderia cepacia complex, Escherichia coli, and Shigella group, Enterobacter cloacae complex, and Pseudomonas putida complex (Pavlovic et al. 2012, Khot and Fisher 2013, Almuzara et al. 2015). Some Bacillus isolates $(15,18,22,35,48,51,52$, 61,66 and 68) had species-level identification only using the MDT technique. The identification of species in the genus Bacillus by classical methods is often difficult, due to similarities between closely related species that share a pattern of morphological, biochemical, and genetic characteristics. These unusual similarities are particularly evident among members of the $B$. cereus group showing almost identical 16S rDNA gene sequences and a high level of chromosomal synteny (Rasko et al. 2005).

Acinetobacter sp. also presents difficulties in identification at the species level. This genus comprises more than 50 species, with four that are closely related and difficult to distinguish by either phenotypic or genotypic methods, known as the Acinetobacter calcoaceticus-baumannii complex (ACB). MDT has been employed in the identification of species in the ACB complex (Sedo et al. 2013), showing reproducible detection of subtle mass spectral differences between strains belonging to the same species, but is not reliable for strain typing. Some Acinetobacter isolates (7, 29,72 ) had species-level identification only using the MDT technique.

Sequencing obtained through the $16 \mathrm{~S}$ rDNA classified $56 \%$ of the identified isolates belong to Firmicutes, $25 \%$ to Proteobacteria, $8 \%$ to Other, and $11 \%$ to Actinobacteria. For the MDT analysis, $55 \%$ of the isolates were identified as Firmicutes, $22 \%$ to Proteobacteria, $8 \%$ to Actinobacteria, and $7 \%$ as NRI (no reliable identification) (Fig. 2).

Based on the identifications by two techniques, MDT, and 16S rDNA, we realized that Bacillus sp. was present in all collections and was the most abundant genus. $\mathrm{C} 1$ presents $30 \%$ of isolates belonging to Bacillus sp., C2 had 27\%, C3 had $47 \%$ and the major percentage occurred in $\mathrm{C} 4$, with $53 \%$. This genus is commonly found in industrial wastewater treatment plants (Poleto et al. 2016, Busi et al. 2017), showing its ecological importance in this kind of effluent treatment. Some microorganisms had higher abundance in certain collections, Pseudomonas sp. isolates appears most in C2 (22\%), Lysinibacillus sp. composes $21 \%$ of C3 isolates (Table VI). Another isolates appear transiently and are present only in one of the collections, Arthrobacter creatinolyticus (C1), Aneurinibacillus aneurinilyticus (C2), Pantoea ananatis (C3) and Kosakonia cowanii (C4).

\section{CONCLUSIONS}

With the exception of sulphate-reducing bacteria, activated sludge was the site with higher 


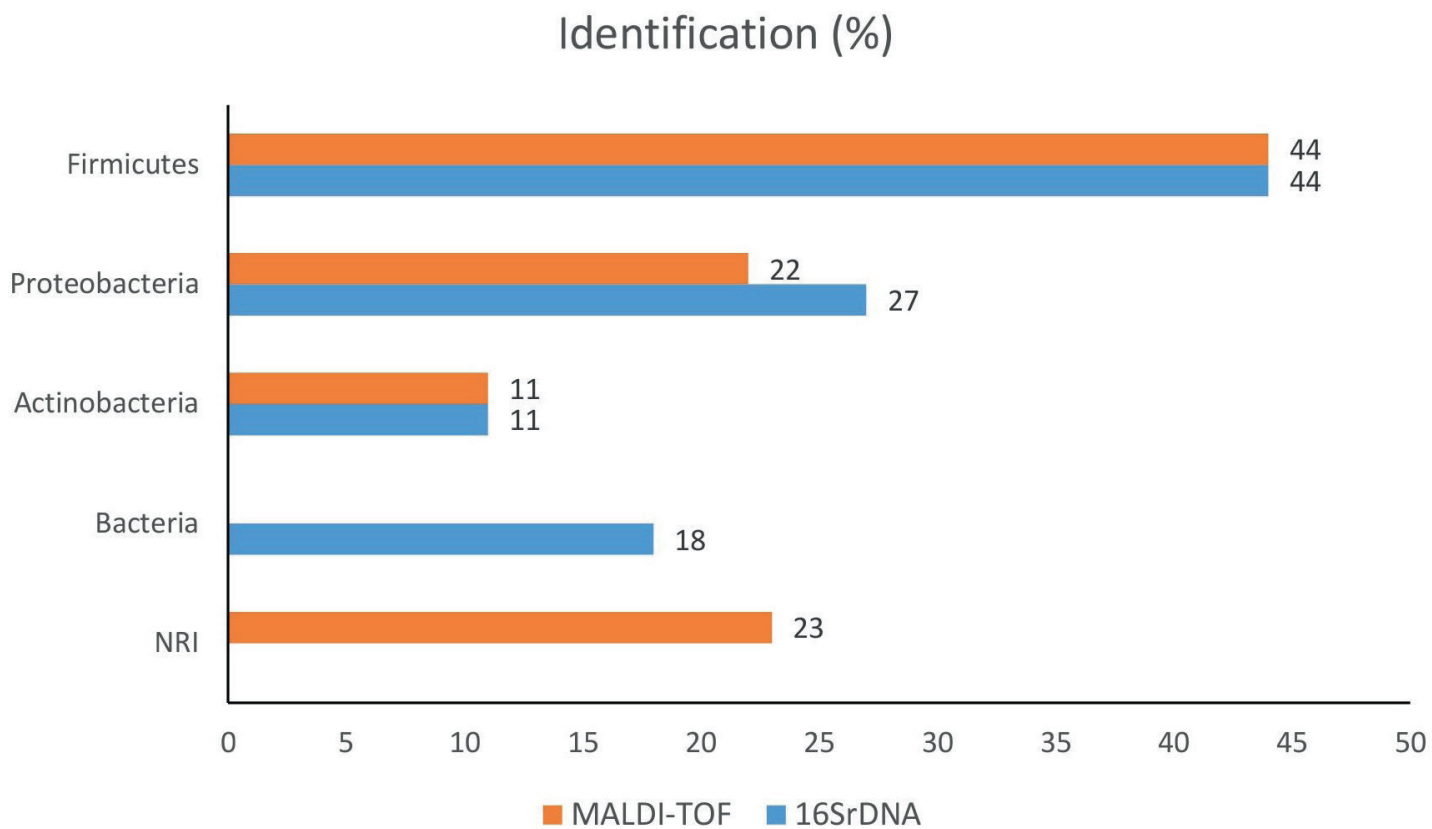

Figure 2 - Comparison of the bacteria identification methods 16S rRNA and MALDI-TOF MS.

quantification of the analyzed microorganisms. In facultative lagoon, the presence of cyanobacteria and algae might have contributed to increasing dissolved oxygen in the effluent and the biological process occurs with the coexistence of cyanobacteria and heterotrophic bacteria. In activated sludge, the presence of dead zones may have favored the metabolism of the denitrifying bacteria. In the present work, the presence of sulfate reducing bacteria (SRB) was observed in all points of collection. In physical-chemical parameters, we observed a reduction in the phosphorus, total nitrogen values and an increase in DO during the treatment of the effluent.

Environmental microbiology is a research area where the use of MALDI-TOF MS remains to be comprehensively explored. Even numbers of ecological studies (sewage, soil, water) have previously applied this technique, each environment presents its particularities according to their location and environmental characteristics. Nevertheless, environmental microorganisms are more diverse and so their identification and characterization pose a significant challenge as the field grows.

In our study, MALDI-TOF MS analysis allowed the identification of $68(93 \%)$ of the 73 isolates at the genus or species level. Comparing with $16 \mathrm{~S}$ rDNA sequencing, the protein profile was able to identify a high taxonomy level identification for Microbacterium sp., Alcaligenes sp., Acinetobacter sp. and Bacillus sp. There was no divergence between the results obtained by the two techniques. Based on this results, we suggest that the MALDI-TOF MS technique can be used as a tool for screening for the identification of bacteria isolated from environmental samples, requiring, in some cases, complementary $16 \mathrm{~S}$ rDNA sequencing.

\section{ACKNOWLEDGMENTS}

We would like to thank Sistema Integrado de Tratamento de Efluentes Líquidos do Polo Petroquímico (SITEL-CORSAN) for authorizing the sample collection. Special thanks go to Angelo Augustinho Massing for accompanying all collections and to Amanda Muliterno Domingues 
Lourenço de Lima for her technical help with the MDT. Thanks also to the Coordenação de Aperfeiçoamento de Pessoal de Nível Superior (CAPES), Conselho Nacional de Desenvolvimento Científico (CNPq), and Fundação de Amparo à Pesquisa no Estado do Rio Grande do Sul (FAPERGS) for their financial support and scholarships grants.

\section{AUTHOR CONTRIBUTIONS}

Themis Antunes: project execution; Ana Elisa Ballarini: help with the molecular biology of the project; Sueli Van Der Sand: project coordination.

\section{REFERENCES}

ALMUZARA M, BARBERIS C, TRAGLIA G, FAMIGLIETTI A, RAMIREZ MS AND VAY C. 2015. Evaluation of matrix-assisted laser desorption ionizationtime- of-flight mass spectrometry for species identification of nonfermenting gram-negative bacilli. J. Microbiol Methods 112: 24-27.

AMORIM CL, MAIA AS, MESQUITA RB, RANGEL AO, VAN LOOSDRECHT MC, TIRITAN ME AND CASTRO PM. 2014. Performance of aerobic granular sludge in a sequencing batch bioreactor exposed to ofloxacin, norfloxacin and ciprofloxacin. Water Res 50: 101-113.

ANA - AGÊNCIA NACIONAL DAS ÁGUAS. 2013. Conjuntura dos recursos hídricos do Brasil. Disponível em: http://arquivos.ana.gov.br/institucional/sge/CE DOC/ Catalogo/2013/conjunturaRecursosHidricos.pdf. Acesso em $01 / 01 / 2017$

APHA - AMERICAN PUBLISHING HEALTH ASSOCIATED. 2005. $21^{\text {st }}$ ed., Standards methods for the examination of water and wastewater. American Public Health Association, Washington, DC.

ATLAS RM. 2005. Handbook of media for environmental microbiology. $2^{\text {nd }}$ ed., FL: Taylor \& Frank Group, Boca Raton, 672 p.

BITTON G. 2005. Introduction to wastewater treatment. In: Wastewater microbiology. Third Edition, J Wiley \& Sons.

BIZZINI A, JATON K, ROMO D, BILLE J, PRODHOM G AND GREUB G. 2011. Matrix-assisted laser desorption ionization-time of flight mass spectrometry as an alternative to $16 \mathrm{~S}$ rRNA gene sequencing for identification of difficult-to-identify bacterial strains. J Clin Microbiol 49: 693-696.

BUSI S, KARUGANTI S, RAJKUMARI J, PARAMANANDHAM P AND PATTNAIK S. 2017.
Sludge settling and algal flocculating activity of extracellular polymeric substance (EPS) derived from Bacillus cereus SK. Water Environ J 31: 97-104.

BUSQUETS A, FORNÓS JJ, ZAFRA F, LALUCAT J AND MERINO A. 2014. Microbial communities in a coastal cave: Cova des Pas de Vallgornera (Mallorca, Western Mediterranean). Int J Speleol 43: 205-216.

CALIJURI MC, ALVES MAS AND DOS SANTOS ACA. 2006. Cianobactérias e cianotoxinas em águas continentais. São Carlos: Rima, 118 p.

CHANG CY, TANONG K, XU J AND SHON H. 2011. Microbial community analysis of an aerobic nitrifyingdenitrifying MBR treating ABS resin wastewater. Bioresour Technol 102(9): 5337-5344.

EDWARDS U, ROGALL T, BLOCKER H, EMDE M AND BOTTGER EC. 1989. Isolation and direct complete nucleotide determination of entire genes. Characterization of a gene coding for $16 \mathrm{~S}$ ribosomal. RNA Nucleic Acids Res 17: 7843-7853.

FORSTER S, LAPPIN-SCOTT HM, SNAPE JR AND PORTER J. 2003. Rains, drains and active strains: towards online assessment of wastewater bacterial communities. J Microbiol Methods 55: 859-864.

GARBEVA P, VAN VJA AND VAN ELSAS JD. 2003. Predominant Bacillus spp. in agricultural soil under different management regimes detected via PCR-DGGE. Microb Eco 45: 302-316.

GLASS C AND SILVERSTEIN J. 1998. Denitrification kinetcs of high nitrate concentration water: $\mathrm{pH}$ effect on inhibition and nitrite accumulation. Water Res 32: 831839.

GRUNDITZ C AND DALHAMMAR G. 2001. Development of nitrification inhibition assays using pure cultures on Nitrosomonas and Nitrobacter. Water Res 35(2): 433-440.

GUO Y, ZHOU X, LI Y, LI K, WANG C, LIU J, YAN D, LIU Y, YANG D AND XING J. 2013. Heterotrophic nitrification and aerobic denitrification by a novel Halomonas campisalis. Biotechnol Lett 35: 2045-2049.

HAGMAN M, NIELSEN JL, NIELSEN PH AND JANSEN J. 2008. Mixed carbon sources for nitrate reduction in activated sludge-identification of bacteria and process activity studies. Water Res 42: 1539-1546.

HAMMER O, HARPER DAT AND RYAN PD. 2001. PAST: Paleontological statistics software package for education and data analysis. Palaeontol Electron 4(1): 9.

HENZE M, KRISTENSEN GH AND STRUBE R. 1994. Rate-capacity characterization of wastewater for nutrient removal processes. Water Sci Technol 29: 101-107.

HIDAKA T, YAMADA H, KAWAMURA M AND TSUNO H. 2002. Effect of dissolved oxygen conditions on nitrogen removal in continuously fed intermittent-aeration process with two tanks. Water Sci Technol 45(12): 181-188.

JESCHKE C, FALAGÁN C, KNÖLLER K, SCHULTZE M AND KOSCHORRECK M. 2013. No Nitrification in Lakes Below pH 3. Environ Sci Technol 47: 14018-14023. 
JOO HS, HIRAI M AND SHODA M. 2005. Characteristics of ammonium removal by heterotrophic nitrification-aerobic denitrification by Alcaligenes faecalis No. 4. J Biosci Bioeng 100: 184-191.

JU F, GUO F, YE L, XIA Y AND ZHANG T. 2014. Metagenomic analysis on seasonal microbial variations of activated sludge from a full-scale wastewater treatment plant over 4 years. Environ Microbiol Rep 6: 80-89.

KADLEC RH AND KNIGHT RL. 1996. Treatment wetlands. Lewis Publishers, Boca Raton.

KHOT P AND FISHER M. 2013. Novel approach for differentiating Shigella species and Escherichia coli by matrix-assisted laser desorption ionization-time of flight mass spectrometry. J Clin Microbiol 51: 3711-3716.

KIM M, JEONG SY, YOON SJ, CHO SJ, KIM YH, KIM MJ, RYU EY AND LEE SJ. 2008. Aerobic denitrification of Pseudomonas putida $\mathrm{AD}-21$ at different $\mathrm{C} / \mathrm{N}$ ratios. $\mathrm{J}$ Biosci Bioeng 106: 498-502.

KOPCAKOVA A, STRAMOVA Z, KVASNOVA S, GODAN A, PERHACOVA S AND PRISTAS P. 2014. Need for database extension for reliable identification of bacteria from extreme environments using MALDI-TOF mass spectrometry. Chem Pap 68(11): 1435-1442.

KOUBEK J, UHLIK O, JECNA K, JUNKOVA P, VRKOSLAVOVA J, KURZAWOVA V, MACEK T AND MACKOVA M. 2012. Whole-cell MALDI-TOF: Rapid screening method in environmental microbiology. Int Biodeterior Biodegradation 69: 82-86.

LAWRENCE FM. 2014. Risk of transmission of carbapenemresistant Enterobacteriaceae and related "superbugs" during gastrointestinal endoscopy. World J Gastrointest Endosc 6(10): 457-474.

MANZ W, EISENBRECHER M, NEU TR AND SZEWZYK U. 1998. Abundance and spatial organization of Gram negative sulfate-reducing bacteria in activted sludge investigated by in situ probing with specific 16S rRNA target oligonucleotides. FEMS Microbiol Ecol 25: 43-61.

MCILROY SJ, STARNAWSKA A, STARNAWSKI P, SAUNDERS AM, NIERYCHLO M, NIELSEN PH AND NIELSEN JL. 2016. Identifying active denitrifiers in activated sludge. Environ Microbiol 18: 50-64.

MENDONÇA LC. 2002. Microbiologia e cinética de sistema de lodos ativados como pós-tratamento de efluente de reator anaeróbio de leito expandido. Dissertação de Doutorado, Universidade de São Paulo, São Paulo, 240 p.

METCALF AND EDDY. 2003. Wastewater Engineering Treatment Disposal Reuse. $4^{\text {th }}$ ed., McGraw, Hill Book, New York.

MOLS M, DE BEEN M, ZWIETERING M, MOEZELAAR R AND ABEE T. 2007. Metabolic capacity of Bacillus cereus strains ATCC 14579 and ATCC 10987 interlinked with comparative genomics. Environ Microbiol 9(12): 2933-2944.
MORALES FI, KELLNER E AND CORDEIRO JS. 2014. Avaliação da qualidade do efluente de lagoa de estabilização em relação à Resolução CONAMA 430/2011: estudo de caso da ETE Santa Eudóxia - São Carlos, SP. Revista Nacional de Gerenciamento de Cidades 2(8): 39-54.

MORGAN-SAGASTUME F, NIELSEN JL AND NIELSEN PH. 2008. Substrate-dependent denitrification of abundant probe-defined denitrifying bacteria in activated sludge. FEMS Microbiol Ecol 66: 447-461.

MUÑOZ C, ROJAS D, CANDIA O, AZOCAR L, BORNHARDT C AND ANTILEO C. 2009. Supervisory control system to enhance partial nitrification in an activated sludge reactor. Chem Eng J 145(3): 453-460.

NACHTIGALLG, JESUS AG, ANGELIS D, SANTESTEVAN NA, MINOTTO E, MOURA TM, D’AZEVEDO P, SAND STVD, FRAZZON J AND FRAZZON APG. 2013. Diversidade e perfil de susceptibilidade antimicrobiana de Enterococcus sp. isolados das águas do Arroio Dilúvio. Porto Alegre, RS, Brasil. Rev Bras Bioci 11: 235-241.

OSAKA T, YOSHIE S, TSUNEDA S, HIRATA A, IWAMI N AND INAMORI Y. 2006. Identification of acetate- or methanol-assimilating bacteria under nitrate-reducing conditions by stable-isotope probing. Microb Ecol 52: 253-266.

PATIL VS, SALUNKHE RC, PATIL RH, HUSSENEDER C, SHOUCHE YS AND RAMANA VV. 2015. Enterobacillus tribolii gen. nov., sp. nov., a novel member of the family Enterobacteriaceae, isolated from the gut of a red flour beetle, Tribolium castaneum. Antonie Leeuwenhoek 107: 1207-1216.

PAVLOVIC M, KONRAD R, IWOBI AN, SING A, BUSCH U AND HUBER I. 2012. A dual approach employing MALDI-TOF MS and real-time PCR for fast species identification within the Enterobacter cloacae complex. FEMS Microbiol Lett 328: 46-53.

PIEKUTIN J AND SKOCZKO I. 2016. Removal of petroleum compounds from aqueous solutions in the aeration and reverse osmosis system. Desalin Water Treat 57: 1213512140 .

PIRSAHEB M, FAZLZADEHDAVIL M, HAZRATI S, SHARAFI K, KHODADADI T AND SAFARI Y. 2014. A survey on nitrogen and phosphor compound variation processes in wastewater stabilization ponds. Pol J Environ Stud 23(3): 831-834.

POLETO L, SOUZA P, MAGRINI FE, BEAL LL, TORRES PR, SOUSA MP, LAURINO JP AND PAESI S. 2016. Selection and identification of microorganisms present in the treatment of wastewater and activated sludge to produce biohydrogen from glycerol. Int J Hydrog Energy 41(7): 4374-4381.

RAHI P, PRAKASH O AND SHOUCHE YS. 2016. MatrixAssisted Laser Desorption/ Ionization Time-of-Flight Mass-Spectrometry (MALDI-TOF MS) Based Microbial 
Identifications: Challenges and Scopes for Microbial Ecologists. Front Microbiol 7: 1359.

RASKO DA, ALTHERR MR, HAN CS AND RAVEL J. 2005. Genomics of the Bacillus cereus group of organisms. FEMS Microbiol Rev 29(2): 303-29.

RUELLE V, EL MOUALIJ B, ZORZI W, LEDENT P AND DE PAUW E. 2004. Rapid identification of environmental bacterial strains by matrix-assisted laser desorption/ ionization time-of-flight mass spectrometry. Rapid Commun Mass Spectrom 18: 2013-2019.

SEDO O, NEMEC A, KRÍ L, ZOVÁ C, KACALOVÁ M AND ZDRÁHAL Z. 2013. Improvement of MALDI-TOF MS profiling for the differentiation of species within the Acinetobacter calcoaceticus-Acinetobacter baumannii complex. Syst Appl Microbiol 36: 572-578.

SOARES J. 1996. Nitrogen removal in waste stabilization ponds on northest Brazil. Ph.D. Thesis, Department of Civil Engineering, University of Leeds, UK.

STACKEBRANDT E AND LIESACK W. 1993. Nucleic acids and classification. Academic Press, London.

SURAMPALLI RY, TYAGI RD, SCHEIBLE OK AND HEIDMAN JA. 1997. Nitrification, denitrification and phosphorus removal in sequential batch reactors. Bioresour Technol 61: 151-157.

SVENSSON H, HANSSON H AND HOGLAND W. 2015. Determination of nutrient deficiency in stormwater from the wood industry for biological treatment. Clean - Soil, Air, Water 43(1): 38-43.

TALLEC G, GARNIER J, BILLEN G AND GOUSAILLES M. 2008. Nitrous oxide emissions from denitrifying activated sludge of urban wastewater treatment plants, under anoxia and low oxygenation. Bioresour Technol 99: 2200-2209.

TIAN M, ZHAO F, SHEN X, CHU K, WANG J, CHEN S, GUO Y AND LIU H. 2015. The first metagenome of activated sludge from full-scale anaerobic/anoxic/oxic (A2O) nitrogen and phosphorus removal reactor using Illumina sequencing. J Environ Sci 35: 181-190.

TONETTI AL, FILHO BC, GUIMARAES JR, FADINI PS AND NICOLAU CE. 2013. Desnitrificação em um sistema simplificado de tratamento de esgoto. Eng Sanit Ambient 18(4): 381-392.

UEHARA MY AND VIDAL WL. 1989. Operação e manutenção de lagoas anaeróbias e facultativas. São Paulo, CETESB. Série Manuais.

URWYLER SK AND GLAUBITZ J. 2016. Advantage of MALDI-TOF MS over biochemical-based phenotyping for microbial identification illustrated on industrial applications. Lett Appl Microbiol 62(2): 130-137.

VALERO MAC, MARA DD AND NEWTON RJ. 2010. Nitrogen removal in maturation waste stabilization ponds via biological uptake and sedimentation of dead biomass. Water Sci Technol 61(4): 1027-1034.
VAN DEN BRAND TP, ROEST K, CHEN GH, BRDJANOVIC D AND VAN LOOSDRECHT MC. 2015. Occurrence and activity of sulphate reducing bacteria in aerobic activated sludge systems. World J Microbiol Biotechnol 31(3): 507-516.

VAN HAANDELAAND MARAIS G. 1999. O Comportamento do Sistema de Lodo Ativado: Teoria e Aplicações para Projetos e Operações. Campina Grande, 472 p.

VON SPERLING M. 2002. Lodos ativados. Princípio de tratamento biológico de águas residuárias. $2^{\mathrm{a}}$ ed. Departamento de Engenharia Sanitária e Ambiental. Universidade Federal de Minas Gerais, Belo Horizonte.

WANG F, HAO HT, SUN R, LI S, HAN R, PAPELIS C AND ZHANG Y. 2014. Bench-scale and pilot-scale evaluation of coagulation pre-treatment for wastewater reused by reverse osmosis in a petrochemical circulating cooling water system. Desalination 335: 64-69.

WATER POLLUTION CONTROL FEDERATION. 1991. Nutrient Control. Prepared by task force on nutrient control. Manual of Pratice $\mathrm{N}^{\circ}$ FD-7. Washington DC.

WEISSBRODT DG, NEU TR, KUHLICKE U, RAPPAZ Y AND HOLLIGER C. 2013. Assessment of bacterial and structural dynamics in aerobic granular biofilms, Front. Microbiol 175.

WINKLER MKH, KLEEREBEZEM R AND VAN LOOSDRECHT MCM. 2012. Integration of anammox into the aerobic granular sludge process for main stream wastewater treatment at ambient temperatures. Water Res 46(1): 136-144.

YANG XP, WANG SM, ZHANG DW AND ZHOU LX. 2011. Isolation and nitrogen removal characteristics of an aerobic heterotrophic nitrifying-denitrifying bacterium, Bacillus subtilis A1. Bioresour Technol 102: 854-862.

YAO S, NI JR, MA T AND LI C. 2013. Heterotrophic nitrification and aerobic denitrification at low temperature by a newly isolated bacterium, Acinetobacter sp. HA2. Bioresour Technol 139: 80-86.

YE L AND ZHANG T. 2013. Bacterial communities in different sections of a municipal wastewater treatment plant revealed by $16 \mathrm{~S}$ rDNA 454 pyrosequencing. Appl Microbiol Biotechnol 97: 2681.

YIMING S, JIGUO Q, DONGZHI C, JIEXU Y AND JIANMENG C. 2016. Characterization of the novel dimethyl sulfide-degrading bacterium Alcaligenes sp. SY1 and its biochemical degradation pathway. J Hazard Mater 304(5): 543-552.

ZHAO B, HE YL, HUGHES J AND ZHANG XF. 2010. Heterotrophic nitrogen removal by a newly isolated Acinetobacter calcoaceticus HNR. Bioresour Technol 101: 5194-5200.

ZHU G, YONGZHEN P, BAIKUN L, GUO J, YANG Q AND WANG S. 2008. Biological removal of nitrogen from wastewater. Rev Environ Contam Toxicol 192: 159-195. 